\title{
Kualitas Fisik Cangkang Telur Ayam Arab dengan Ransum Kombinasi Azolla microphylla dan Sumber Mineral Kalsium Berbeda
}

\section{Physical Quality of Arabian Chicken Egg Shells with Diet Combination of Azolla microphylla and Different Calcium Mineral Sources}

\author{
Eudia Christina Wulandari ${ }^{1}$, Wahyuni $\mathrm{H} \mathrm{I}^{2}$, Suthama $\mathrm{N}^{2}$ \\ ${ }^{1}$ Fakultas Peternakan, Jurusan Peternakan, Universitas Boyolali \\ ${ }^{2}$ Fakultas Peternakan dan Pertanian, Jurusan Peternakan, Universitas Diponegoro \\ eudia1990.christina@gmail.com
}

\begin{abstract}
The aim of the present research was to evaluate the contribution effect of calcium derived from Azolla microphylla and different mineral sources on egg shell in Arab hen. Ninety six birds of Arab hen, age was \pm 16 weeks, with an average body weight of 814,73 $\mathrm{g} \pm 46,86 \mathrm{~g}$ were used as experimental animals, and were divided randomly into a randomized block design with 6 treatments and 4 replications. Feedstuffs used for dietary treatments were rice bran, yellow corn, poultry meat meal, Azolla microphylla, $\mathrm{CaCO}_{3}$, $\mathrm{Ca}_{2} \mathrm{HPO}_{4}$, oyster shell, palm oil, and top mix. The rations were formulated approximately iso metabolizable energy and iso protein of $3100 \mathrm{kkal} / \mathrm{kg}$ and $17 \%$ respectively. Inclusion levels of Azolla microphylla 6\% in the ration were categorized as treatments, namely, Azolla microphylla 6\% without different mineral source (T1); Azolla microphylla 6\% and $3 \% \mathrm{CaCO}_{3}$ and $6 \%$ oyster shell (T2); Azolla microphylla $6 \%$ and $3 \% \mathrm{Ca}_{2} \mathrm{PO}_{4}$ and $6 \%$ oyster shell (T3). Conclusion of the research is that calcium retentions are not inhibited by the Azolla microphylla, moreover it can increase calcium deposited in egg shell.
\end{abstract}

Keywords: Arabian chicken, eggshell, Azolla micophylla, mineral

\section{PENDAHULUAN}

Indonesia sangat beragam kekayaan alamnya. Bukan hanya tumbuhan, tetapi hewan sebagai bidang olahan peternakan. Salah satu komoditas yang berkembang adalah ayam Arab. Ayam Arab memiliki komoditas dwiguna, yakni petelur dan pedaging. Sebagai ayam petelur, Ayam Arab memiliki tingkat produktivitas mencapai $70 \%$. Telurnya berkerabang putih dengan pemeliharaan relatif mudah.

Produktivitas yang tinggi harus didukung oleh kebutuhan yang optimal. Kebutuhan yang optimal dipenuhi saat fase pullet, sebagai tolak ukur produktivitas fase layer. Pada fase ini, merupakan fase kritis yang harus dimonitoring maksimal. Disamping itu, ketersediaan kalsium sebagai pendukung produktivitas wajib dipenuhi. Hal ini mengingat tingkat keberhasilan produksi bergantung pada keseimbangan kalsium dalam tubuh.

Salah satu bahan pakan alternatif yang dapat digunakan adalah Azolla microphylla. Azolla microphylla merupakan salah satu tanaman air yang memiliki protein kasar $23,7 \%$, serat kasar $15 \%$, lemak kasar 2,93\%, kalsium 2,07\%, dan phosphor 0,77\% (Lukiwati et al., 2008). Serat kasar yang tinggi dapat mengurangi pemanfaatan nutrisi yang lainnya (Gonzales-Alvarado et al., 2007). Penelitian Wulandari et al. (2012) dengan menggunakan level penggunaan 
Azolla microphylla 0, 3, 6, dan 9\% terhadap pemanfaatan kalsium dan phosphor pada cangkang telur ayam Arab. Hasil penelitian ini menunjukkan bahwa level penggunaan 6\% Azolla microphylla adalah yang paling efektif dalam pemanfaatan mineral. Pada level 9\%, penggunaan Azolla microphylla nyata mengurangi pemanfaatan kalsium dan phosphor terlepas dari retensi yang nyata meningkat.

Serat kasar yang tinggi ini dapat diimbangi dengan penambahan mineral dalam ransum. Berdasarkan penelitian Wulandari et al. (2012) tersebut, maka dilakukan penelitian pemanfaatan Azolla microphylla sebagai sumber protein nabati dan mineral beserta kombinasinya dengan mineral berbeda. Beberapa mineral yang digunakan dalam usaha peternakan antara lain $\mathrm{CaCO}_{3}, \mathrm{Ca}_{2} \mathrm{PO}_{4}$, dan cangkang kerang. Tujuan penelitian ini adalah untuk mengetahui kekurangan dan kelebihan Azolla microphylla sebagai salah satu potensi bahan pakan. Manfaat dari penelitian ini adalah mengetahui respon biologis Ayam Arab terhadap keberadaan serat kasar dan mineral kalsium.

\section{MATERI DAN METODE}

Ternak yang digunakan adalah 96 ekor ayam Arab betina periode pullet umur \pm 16 minggu dengan rerata bobot badan $814,73 \mathrm{~g} \pm 46,86$. Bahan penyusun ransum adalah bekatul, jagung kuning, poultry meat meal, bungkil kedelai, tepung Azolla microphylla, $\mathrm{CaCO}_{3}, \mathrm{Ca}_{2} \mathrm{PO}_{4}$, tepung kulit kerang, indikator ferri oksida untuk pewarna ekskreta pada pengukuran retensi asam amino, kalsium. $\mathrm{HCl} 0,1 \mathrm{~N}$ berfungsi untuk mengurangi jumlah $\mathrm{N}$ yang terbang saat total koloeksi.Vaksin ND lasota, vaksin coryza digunakan selama pemeliharaan yang digunakan setiap 8 minggu sekali dan pada umur 12 minggu. Peralatan yang digunakan adalah kandang baterai,egg tray, tempat ransum dan minum, mikrometer sekrup untuk mengukur ketebalan cangkang telur, timbangan dengan ketelitian $0,01 \mathrm{~g}$ dan $1 \mathrm{~g}$. Formula ransum perlakuan dan kandungan nutrisi selengkapnya untuk masing-masing perlakuan disajikan pada Tabel 1.

Penelitian menggunakan rancangan acak lengkap dengan 3 perlakuan (Tabel 1) dan 6 ulangan, masing-masing 4 ekor ayam. Ransum perlakuan yang masing-masing mulai diberikan pada periode pullet sampai periode bertelur pertama. Ransum perlakuan adalah sebagai berikut :

T1 : ransum perbaikan menggunakan Azolla microphylla 6\% sebagai sumber kalsium,

T2 : ransum perbaikan menggunakan Azolla microphylla $6 \%+3 \% \mathrm{CaCO}_{3}+$ $6 \%$ cangkang kerang,

T3 : ransum perbaikan menggunakan Azolla microphylla $6 \%+3 \% \mathrm{Ca}_{2} \mathrm{PO}_{4}+$ $6 \%$ cangkang kerang, 
Tabel 1. Komposisi Ransum Perlakuan Ayam Arab Periode Bertelur dan Kandungan Nutrisi

\begin{tabular}{|c|c|c|c|}
\hline \multirow{2}{*}{ Nutrisi } & \multicolumn{3}{|c|}{ Perlakuan } \\
\hline & T1 & T2 & T3 \\
\hline Jagung Kuning (\%) & 52,00 & 49,00 & 40,00 \\
\hline Bekatul (\%) & 29,00 & 29,00 & 29,00 \\
\hline Poultry Meat Meal (\%) & 6,50 & 6,50 & 6,50 \\
\hline Bungkil Kedelai (\%) & 12,00 & 9,00 & 9,00 \\
\hline Azolla microphylla (\%) & 6,00 & 6,00 & 6,00 \\
\hline $\mathrm{CaCO}_{3}(\%)$ & - & 3,00 & - \\
\hline $\mathrm{Ca}_{2} \mathrm{HPO}_{4}(\%)$ & - & - & 3,00 \\
\hline Tepung Cangkang kerang (\%) & 6,00 & 6,00 & 6,00 \\
\hline Top Mix & 0,50 & 0,50 & 0,50 \\
\hline \multicolumn{4}{|l|}{ Kandungan Nutrien } \\
\hline Energi Metabolisme (kkal/kg)* & 3122,00 & 3134,00 & 3134,00 \\
\hline Protein Kasar (\%) ${ }^{* *}$ & 18,48 & 17,56 & 17,56 \\
\hline Serat Kasar $(\%)^{* *}$ & 9,10 & 8,73 & 8,73 \\
\hline Lemak Kasar (\%) & 7,75 & 7,28 & 7,28 \\
\hline Kalsium $(\%)^{* * *}$ & 0,70 & 3,95 & 3,71 \\
\hline Phosphor $(\%)^{* * *}$ & 0,52 & 0,52 & 1,11 \\
\hline
\end{tabular}

${ }^{*}$ :Dihitung dengan rumus Balton (1967); T0 : ransum tanpa sumber kalsium dan tanpa Azolla microphylla; T1 : ransum menggunakan Azolla microphylla 6\%; T2 :T1+ 3\% $\mathrm{CaCO}_{3}+6 \%$ cangkang kerang; $\mathrm{T} 3: \mathrm{T} 1+3 \% \mathrm{Ca}_{2} \mathrm{PO}_{4}+6 \%$ cangkang kerang.

\section{HASIL DAN PEMBAHASAN}

Seluruh parameter penilitian ini meningkat nyata $(P \leq 0,05)$ karena adanya penggunaan Azolla microphylla dan kombinasinya dengan berbagai mineral berbeda (Tabel 2).

Tabel 2. Konsumsi Ransum, Kalsium dan Phosphor serta Berat Cangkang Telur Ayam Arab Dengan Ransum Kombinasi Azolla microphylla Dengan Sumber Mineral Kalsium Berbeda

\begin{tabular}{lccc}
\hline \hline \multirow{2}{*}{\multicolumn{1}{c}{ Parameter }} & \multicolumn{3}{c}{ Perlakuan } \\
\cline { 2 - 4 } & \multicolumn{1}{c}{ T1 } & T2 & T3 \\
\hline Konsumsi Ransum (g/ekor/hari) & $88,55^{\mathrm{b}}$ & $99,01^{\mathrm{a}}$ & $99,23^{\mathrm{a}}$ \\
Konsumsi Kalsium (g/ekor/hari) & $0,59^{\mathrm{c}}$ & $3,68^{\mathrm{b}}$ & $3,92^{\mathrm{a}}$ \\
Konsumsi Phosphor (g/ekor/hari) & $0,44^{\mathrm{c}}$ & $0,52^{\mathrm{b}}$ & $1,10^{\mathrm{a}}$ \\
Berat Cangkang Telur (g) & $3,15^{\mathrm{b}}$ & $3,95^{\mathrm{a}}$ & $4,10^{\mathrm{a}}$ \\
\hline
\end{tabular}

Superskrip berbeda pada setiap baris yang sama menunjukkan perbedaan yang nyata $(P \leq 0,05)$

Hasil penelitian menunjukkan bahwa konsumsi ransum, kalsium, dan phosphor berbeda nyata. Konsumsi ransum, kalsium, dan phosphor nyata paling rendah $(P \leq 0,05)$ pada ayam yang diberi ransum $T 1$ (Tabel 2$)$. Konsumsi ransum pada ayam yang diberi ransum T1 berbeda nyata dengan T2 dan T3, namun ayam yang diberi ransum T2 dan T3 tidak berbeda nyata. Hal ini memberikan 
arti bahwa palatabilitas ransum merupakan salah satu faktor pendukung konsumsi ransum (Nicol et al., 2002; Donoughuel et al., 2012). Konsumsi kalsium dan phosphor nyata $(P \leq 0,05)$ meningkat sejalan dengan kandungan kalsium dan phosphor ransum yang berbeda-beda (Tabel 1).

Berat cangkang telur dipengaruhi oleh beberapa faktor. Faktor tersebut adalah antara lain keberadaan nutrisi inhibitor, penyerapan nutrisi, suhu, keseimbangan kalsium dan phosphor. Berat cangkang telur pada T3 dan T2 tidak berbeda nyata, $T 1$ nyata $(P \leq 0,05)$ berbeda dengan $T 2$ dan $T 3$. Pada T3 dan T1, berat cangkang dipengaruhi oleh kalsium dan phosphor T3 dan T1. Moreki (2005) menyatakan bahwa kalsium merupakan satu kunci utama untuk produktivitas ayam petelur terutama kualitas fisik telur. Namun, pada T2 dimungkinkan terjadi mobilisasi kalsium dari tulang sehingga berat cangkang tidak berbeda nyata dengan T3. Menurut Moe (2008) bahwa koefisien cerna, konsumsi kalsium dan phosphor yang tidak mendukung akan diseimbangkan oleh mobilisasi kalsium dari tulang.

\section{KESIMPULAN}

Nutrisi Azolla microphylla dapat digunakan sebagai bahan pakan yang dikombinasikan dengan salah satu sumber mineral untuk mendukung produktivitas Ayam Arab fase bertelur.

\section{DAFTAR PUSTAKA}

Donoghue, A. M., J. R. Moyle, J. M. Burke, A. Fanatico, J. A. Mosjidis, T. Spencer, K. Arsi, I. Reyes-Herrera, A. Woo-Ming, and D. J. Donoghue. 2012. Palatability of tannin-rich sericea lespedeza fed to broilers. J. Appl. Poult. Res. 21 : 891-896.

Gonzalez-Alvarado, J.M., E. Jiménez-Moreno, and R. Lázaro. 2007. Effect of type of cereal, heat processing of the cereal, and inclusion of fiber in the diet on productive performance and digestive traits of broilers. J. Poult. Sci.86 : 1705-1715.

Lukiwati, D. R., Ristriarso, P. Dan Wahyuni, H. I. 2008. Workshop 2008 Azolla microphylla as Protein Source for Rabbits. Mekarn Workshop. Cantho University, VietnamMoe, S. M. 2008. Disorders involving calcium, phosphorus, and magnesium. J. Prim. Care. 35 (32) : 215-234

Moreki, J. C. 2005. The Influence of Calcium Intake by Broiler Breeders on Bone Development and Egg Characteristic. Faculty of Natural and Agricultural Sciences, University of the Free State, Afrika Selatan (desertasi).

Nicol, C . J., C. M. Sherwin, and C. M. Heyes. 2002. Social learning influences the preferences of domestic hens for novel food. J. Anim. Behav. 6 (5) : 933-942. 
Wulandari, E. C., R. H. Prawitasari, W. Murningsih, V. D. Yunianto, I. Estiningdrati, and H. I. Wahyuni. 2012. Pengaruh serat kasar Azolla microphylla terhadap pemanfaatan mineral kalsiumdan phosphor ransum serta produksi ayam arab petelur. Dalam Marlina, E. T. ,Abustam, E., Harlia, E., Yamam, A., Nurlina, L., Rahayu, S., Setiyatwan, H., Tasripin, D. S. Nurdin, E., Widjastuti, T. Suryaningsih, L., Rusmana, D., Arief H., Dudi. Prosiding Seminar Nasional Peternakan Berkelanjutan 4, Jatinagor, 7 November 2012, Hal. $182-187$. 